\title{
Phenomenology studies in junior high school students' enthusiasm in school studies learning in Universitas Malang Laboratorium, Indonesia
}

\author{
Heru Wijanarko *, I Dewa Putu Eskasasnanda, Bayu Kurniawan \\ Social Studies Education Study Program, Universitas Negeri Malang. \\ Jl. Semarang No. 5, Sumbersari, Lowokwaru, Malang, Jawa Timur 65145, Indonesia. \\ heru.wijanarko2177@gmail.com \\ * Corresponding Author
}

\section{ARTICLE INFO}

\section{Article History}

Received:

12 May 2020;

Revised:

14 May 2020;

Accepted:

2 December 2020

Keywords

Enthusiasm;

Students;

Social studies learning;

\begin{abstract}
Social science is a common subject given at every level of education. The Social Sciences junior high school curriculum is taught in an integrated manner to facilitate students' social science learning that is important in everyday life. Unfortunately, there are many obstacles encountered in social studies in practice, one of which is the lack of interest and enthusiasm of students in learning social studies. It makes students unable to grasp the importance of social studies. This research conduct on students and teachers of the Junior High School Universitas Negeri Malang Laboratory. This study aims to analyze non-enthusiasm students in social classes learning. This research conduct using descriptive methods with survey research. Data collection techniques used are observation, interview, and documentation data collection tools in observation guidelines and interview guidelines. This study's informants were 17 students taken at each grade level and supported by three informants from social studies teachers who were selected purposes study indicates that UM Lab junior high school students' unenthusiastic behavior when learning social studies is reading comics, singing, drawing, chatting, and joking with friends. The factors that cause it are the amount of material and assignments in modules that must be memorized and memorized. Students are dizzy and confused. It has an impact on their understanding, which is less related to social studies material.
\end{abstract}

This is an open access article under the CC-BY-SA license.

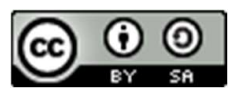

\section{INTRODUCTION}

Effective learning has always been a dream for educators. Not surprisingly, educators strive for various ways so that education carry out the following expectations. Effective learning will have an impact on achieving educational goals. The educational objectives as stipulated in Law Number 20 the year 2003 Regarding National Education System Article 3 reads, national education functions to develop the ability and shape the nation's character and civilization with dignity in the context of educating the life of the nation, and is aimed at developing the potential of students to become human beings who believe in and fear God Almighty, have noble, healthy, knowledgeable, capable, creative, independent, and become democratic and responsible citizens. Through education, high-quality human resources will be produced to improve the nation and state (Widiansyah, 2018). Education nowadays has become the main thing as it involves most people to take part in this matter. In addition, it cannot be separated from human life (Johan \& Harlan, 2014).

Effective learning does not just happen without proper planning. Many factors are needed for educators to achieve effective learning. These factors are divided into two, namely internal and 
external. Internal factors include psychological conditions, namely intelligence, attention, interest, talent, motives, maturity, and readiness (Tobeli, 2010; Djamarah, 2011). External factors include family, school, and community (Rosyid, Mustajab, \& Abdullah, 2003; Beischel, 2013; Hapnita, 2018). One of the things that play an essential role in learning is students' interest or willingness to learn. To participate in learning first, students must be interested in giving birth to motivation or enthusiasm in learning (Yosodipuro, 2012). The digital transformation of education systems has allowed the incorporation of a new teaching-learning ecosystem called e-learning (ValverdeBerrocoso, Garrido-Arroyo, Burgos-Videla, \& Morales-Cevallos, 2020).

Enthusiasm starts from one's interest in one particular thing that causes attention, thus triggering a continuous effort to achieve this goal (Suyono, 2015; Afdhal, 2015). It is in line with Sardiman (2016) statement, which revealed that students would be enthusiastic in learning if students' psychological condition feels happy and interested in learning activities. In real learning in class, many Indonesian students experience learning enthusiasm problems. It often happens in learning with much material, one of which is social studies. Maryani and Syamsudin (2009) explain that social studies education is considered as the second lesson after science because it does not require high ability and tends to be relaxed in learning. Herijanto (2012) revealed that social sciences learning is less attractive, resulting in students' low interest following this learning. While Setyowati and Firmansyah (2018), and Suwarna (2001) found that social studies learning is more memorized and monotonous, does not make students think critically so that it seems to saturate. Monotonous learning can affect learning objectives (Han, Takkaç-Tulgar, \& Aybirdi, 2019).

The solution ever done to increase the enthusiasm of students in social studies learning is through specific learning methods or models, like the research conducted by Qomariyah (2014), which states that the excitement or motivation of learners has increased by treating interactive learning methods using Cooperative Learning Model with Numbered Heads Together (NHT) Techniques. The results of Suciyanto's (2013) study stated that shiva's interest or enthusiasm in studying social studies subjects increased by using the crossword puzzle method. In practice, not all schools use this method and not all learners according to the learning mode. Aside from the learning model, the learning and teaching process cannot be separated from the ICT (Information and Communication Technology) role (Suryati \& Suryana, 2019).

Today, technology plays a very important role in our life (Raja \& Nagasubramani, 2018). The problem of the lack of enthusiasm of students towards social studies learning also occurs in Malang. Sari and Kurniawati's research (2015) found that education lasted a lot during social studies. It found learners chatting, joking, daydreaming, and even leaving the classroom when they explained the subject matter. Problems related to enthusiasm learners in social studies learning are exciting topics to study through research to students' enthusiasm for social studies subjects. Passion is a significant factor that can contribute to student achievement. Passionate teachers who are strongly committed to their work can make a positive difference in student achievement. In addition to being a motivating factor, passion can positively influence learning and teaching by creating excitement and action (Serin, 2017).

The research will be conducted at the Junior High School Negeri Malang State Laboratory, or abbreviated as Junior High School Lab. UM. This school is located at Simpang Bogor Street No.T7, Sumber Sari, District Lowokwaru, Malang City, East Java. Junior High School Lab. UM is a private junior high school included in the most popular school of Malang people to send their children to school, especially for middle and upper economic families. It is evidenced by the UM LAB Junior High School successfully ranked second after the Catholic St. Joseph Malang Middle School in the category of selected private Junior High School in Malang in 2015 (Fitriana \& Triwiyanto, 2015).

Based on the facts above, the researcher is interested in studying the causes of the lack of enthusiasm of students of Junior High School Lab. UM in social studies learning. It is interesting because integrated social studies is an Integrated subject between geography, economics, sociology, history, anthropology, and politics (Ibrohim, 2018). The wide variety of social studies topics should make social studies an exciting subject because they can be studied from various perspectives from social science disciplines. However, the reality on the ground is inversely proportional to the statement. The phenomenon of student interest in social science learning will be found in this study paper.

Volume 7, No. 2, September 2020 


\section{METHOD}

This research uses a qualitative approach. Qualitative research aims to describe and analyze phenomena, events, social activities, beliefs, and individual and group thinking (Sukmadinata, 2013). According to Moleong (2013), qualitative research aims to understand the phenomena experienced by research subjects, both behavior, perception, motivation, and action holistically in the form of words and language descriptions in specific contexts naturally (Rukajat, 2018). Qualitative research has natural environmental characteristics, researchers as instruments, various methods, complex thinking through inductive and deductive logic, new and dynamic design, reflectivity, and holistic discussion (Cresswell, 2014). This type of research used in this research is descriptive qualitative research. According to Nawawi (1993), Descriptive research is a problem-solving procedure that is investigated by describing the subject and object of research (individuals, groups, institutions, and society) in the present situation based on facts that appear as they are. Based on the above characteristics, the type of descriptive research is felt to be following research conducted by researchers. In this study, the researchers tried to describe the condition and enthusiasm of the students of Junior High School Laboratory Universitas Negeri Malang in social studies learning.

Data collectors are observation, interview, and documentation data collection tools in observation guidelines and interview guidelines. This study's population was 17 students taken at each grade level and supported by three informants from social studies teachers selected purposively. This study uses data analysis techniques interactive model Miles and Huberman (2014) can be seen in Figure 1.

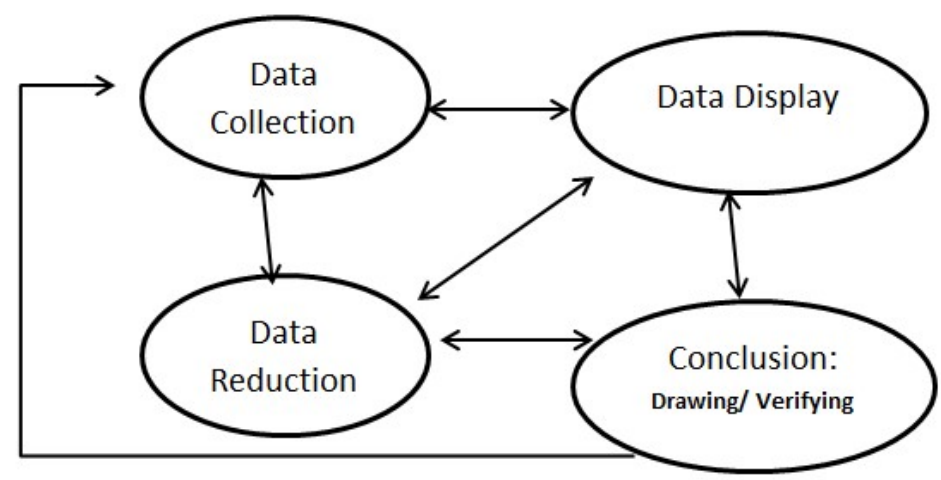

Figure 1. Interactive Model Data Analysis Techniques

(Sources: Miles \& Huberman, 2014)

\section{FINDINGS AND DISCCUSIONS}

Forms of Student Enthusiasm Behavior in Social Studies Learning

In the practice of learning in class, it is often encountered by students who are enthusiastic about learning. Lack of enthusiasm in education is when students do not have enthusiasm for learning, so students cannot complete their assignments correctly. Students' enthusiasm can be seen from their non-verbal behavior that does not show interest during learning. Based on research at Junior High School Lab. Universitas Negeri Malang, when students are enthusiastic about learning, they often do the behavior that is not related to the lesson.

The study's findings show that the behavior of non-enthusiast students of Junior High School Lab Universitas Negeri Malang in social studies learning is divided into individual behavior and social behavior. Individual behavior is a personal response to an object related to the likes or traits attached to the individual (Gerungan, 2010). In contrast, social behavior is the same action carried out by two or more people repeatedly to a particular object or condition (Nurfirdaus \& Risnawati, 2019). The individual behavior of the students of Junior High School Lab. UM, that leads to the lack 
of enthusiasm in learning is drawing, singing, sleeping, and reading comics. The social behavior that they usually do with their friends when they are enthusiastic about learning is chatting, joking, and making jokes in class, see Table 1 . The behavior appears as a response from the saturation that is naturally experienced by students when learning. According to Schaufeli and Enzmann (1998), the indicators of learning burnout are emotional exhaustion, physical exhaustion, cognitive exhaustion, and loss of learning motivation.

Table 1. Student Enthusiasm Behavior in Learning

\begin{tabular}{cll}
\hline \multirow{2}{*}{ No. } & \multicolumn{1}{c}{ Forms of student enthusiasm behavior } \\
\hline 1 & Write and draw yourself & \multicolumn{1}{c}{ Chat with friends. } \\
2 & Play alone, look out the window & $\begin{array}{l}\text { Joking with a friend. } \\
\text { Celometan and make jokes that disturb class } \\
\text { peace. }\end{array}$ \\
3 & Lie down, put your head on the table & \\
4 & Just stay quiet, don't listen to the teacher & \\
5 & Read comics \\
6 & Permission to go out to the bathroom & \\
7 & Sing alone \\
8 & Lazy writes & \\
9 & Crowded yourself \\
10 & $\begin{array}{l}\text { Spontaneous speaking that is unrelated to } \\
\text { the lesson }\end{array}$ \\
\hline
\end{tabular}

Influencing Factors of Unusiusiveness Students in Social Studies Learning

In social studies learning activities in class, two factors influence students in learning. External and internal factors influence student success in education. In line with this, external factors originate from the environment in which students learn, while internal factors create from within students, both physiological, and psychological aspects.

\section{External Factors}

Social study is a subject with various subjects. Therefore a lot of material and concepts must be learned and understood by students. Many social studies material makes teachers feel overwhelmed because they are required to deliver the entire material to students. Junior High School Lab UM has a policy that all learning is done using a module system. Like implementing other lessons, social studies learning in Junior High School Lab UM is carried out using modules. Modules are teaching materials that are arranged systematically, including materials, methods, and learning evaluation. Students can use modules independently to achieve competencies and learning objectives. Module as a learning device has the advantage that it can make students motivated to learn, because they can work on problems according to their abilities. Through modules, the learning load can also be distributed evenly throughout the semester so that education can be more efficient.

In social studies learning in Junior High School Lab. UM, it is known that the necessity to teach social studies material using modules makes teachers often experience difficulties. Due to many social studies materials and learning modules that must complete, teachers often ask students to work on module assignments to achieve learning material. In practice, this often makes students quickly feel bored because they have to do the module for a long time. According to Bildhonny (2017), saturation is a mental condition when a person experiences extreme enthusiasm and fatigue, which results in feeling reluctant, lethargic, and not eager to do activities. Enthusiasm can make students experience a loss of confidence in carrying out learning activities. Saturation of knowledge often occurs because of the demands for students always to obey the rules and complete the tasks given to them. School demands that require good learning outcomes make students burdened and ultimately enthusiastic in learning. That student learning outcomes can be enhanced through 
contextual teaching and learning (Marini. 2016). Learning outcomes of a course or program clearly show what the student will achieve at the end of the course or program (Mahajan \& Singh, 2017).

\section{Internal Factors}

Many materials students must learn in social studies make students have the necessity to memorize the material. Student's mastery of the material is essential as they prepare to take the exam. According to Indianto (2015), memorization is an activity of moving reading material or objects into memory (encoding), storing in long-term memory (storage), so that at any time it can be expressed again if needed (retrieval). At the time of social studies, learning, memorizing concepts, and materials preparing for the exam made students bored and dizzy because the brain is unable to remember. Brain will be more comfortable remembering something meaningful that has happened or experienced and is often encountered in an adjacent order. Students will also memorize when allowed to repeat and practice longer. This research shows that conducive conditions for learning and understanding the material do not occur in social studies subjects because of the large amount of material and short learning time. According to Kwan \& Mafe (2016), memorizing learning causes student understanding to decrease. According to Truong, Ngoc, \& Samad (2019), memorizing learning causes language skills not to develop.

\section{The Impact of Student's Enthusiasm in Social Studies Learning}

The impact or effect occurs on someone's decision or action. As a result of students' enthusiasm for participating in social studies learning in class, they receive two negative impacts. First is the effect on himself personally (personal influence), and the other consequence is the impact on friends (social impact). Based on the research, it is known that the individual impact of students' non-enthusiasm in social studies makes students unable to understand the subject matter, cannot work on evaluation questions, and leads to their poor grades (under KKM). According to Winkel, Saegert, and Evans (2009), the ability to understand lessons occurs when students can pay attention and focus on the teacher who is explaining the material. It did not happen to students at UM Lab Middle School. As a result of feeling bored when social studies teachers present the material, some students are busy chatting with friends, daydreaming, and even falling asleep. It causes the teacher's explanation can not be adequately heard, so they do not understand.

Aside from individual impacts, students' lack of enthusiasm during social studies also has a social impact. Based on research, it is known that when students are enthusiastic about learning, they tend to conduct behaviors that can disrupt class peace or distract friends' learning focus. According to Wicaksono (2013), when students are enthusiastic about learning, they tend to do something that can express their enthusiasm. It is what sometimes causes noise in the classroom.

Based on the study results, note that students' lack of enthusiasm leads to learning disabilities in students and classmates caused by not matching what students want with the form of learning conducted by the teacher. According to Gettinger and Seibert (2001), the teacher's inappropriate action during learning with students' desires can make students experience learning difficulties. Furthermore, according to Bosah, Ejesi, and Doris (2016), this discrepancy can result in the appearance of disruptive behavior during the learning process.

\section{Teachers' Efforts to Increase Student Enthusiasm in Social Studies Learning}

As a result of feeling the students' behavior seemed less enthusiastic during social studies learning, the Social Sciences teachers of Junior High School Lab. UM tried to implement a learning method to make students active and enthusiastic about learning. The teacher's learning methods are adjusted to the teacher's nature and teaching style, and their view of the learning method most effectively makes students active. One of the teachers is known to try to provide outdoor learning forms and field observation activity assignments. This form of learning has a goal so that students have the opportunity to learn directly. The facts that occur indicate that this method helps students become active and eager to learn. The findings show that regarding outdoor learning is appropriate. Through outdoor learning, students will be enthusiastic because they will get hands-on learning experiences in the field, learn concrete lesson materials, and enrich their learning experiences. 
Outdoor learning can change perceptions and increase students' sensitivity or concern for the environment. The teacher asks students to conduct field observations related to modern markets and transitional markets based on research. Students can find out that items sold in traditional markets tend to be more diverse than modern needs such as supermarkets and malls. Also, in terms of service and price, traditional markets have flexible prices. They can be negotiable, while prices tend to remain but have a more comfortable shopping level in modern markets. Students from books cannot obtain this, so it is proven that outdoor learning can change or complement students' perceptions of learning.

Unlike the teachers who implement outdoor learning, the other two Social Sciences teachers feel comfortable staying in indoor education. One teacher innovates learning by asking students to make crossword questions (TTS). As a group, students ask to create items that will be done by other groups. This method is proven to make students interested and enthusiastic in learning. The students' interest can be seen from how they arrange the TTS questions until the social studies learning time ends and even continues on the porch of the muscle or at a friend's house after school. According to Bandura (1994), someone will tend to be involved in something if he believes he can do that and get praise for it. It is known as Self Efficacy. This research shows that learning makes students enthusiastic and active by making TTS questions answered by friends or other groups. Students feel that they can also make questions as their teacher does; therefore, they compete to create difficult items for their friends to answer, so they get praise from the teacher for their abilities and knowledge.

Other teachers who do in-door learning try to intersperse small lessons with ice-breaking activities to reduce student tension during the learning process. According to Soenarno (2005), Ice Breaking is a way to create a conducive atmosphere, to reunite thoughts and actions to a single point of attention to make students focus. A conducive atmosphere is a condition that is needed so that students have interest, enthusiasm, and endurance of learning (Arianti. 2017). When the learning atmosphere is no longer conducive to social studies learning, students seem unenthusiastic and preoccupied with chatting or joking with their friends. One of the teachers tries to do ice-breaking to make the students' attention return to learning. The teacher asks all students to stand up and do the jogging together that is trending on social media. It can make students refocus and do these activities happily so that their minds are refreshed.

Related to this phenomenon, Goleman (1998) explains that when the brain receives pressure or threats, the capacity of nerves to reason becomes smaller. In this condition, the brain cannot process higher-level learning activities (Higher-order thinking skills). The monotonous and pressing social studies learning needs can make students lose the ability to accept the teacher's explanation. To overcome this, the teacher carries out the Ice Breaking activity to maintain student concentration in learning.

\section{CONCLUSION}

The implementation of learning in Junior High School Lab UM uses modules as a learning resource. Modules are teaching materials made by teachers, containing material, methods, and evaluation questions for learning. The use of modules aims to simplify or focus the subject matter to understand the subject matter easily. In the implementation of learning using modules, the number of material students must learn in social studies. The questions that must do as an evaluation make many students feel tired and bored. In module-based learning, many teachers ask students to read the material and do the module exercises to achieve completeness of the material. It makes many students unenthusiastic during social studies learning because it seems monotonous, just reading and working on problems. Monotonous learning that only works on the next module creates negative conditions and behaviors due to students' lack of enthusiasm in the lesson. Students' lack of confidence in social studies makes students miss much material, so it is not easy when working on exam questions. Meanwhile, during learning, students who are enthusiastic about learning in class tend to do activities that can disrupt other students' concentration and class calmness.

Due to the saturation of social studies learning using modules, students' lack of enthusiasm makes teachers make various efforts to make students more enthusiastic in learning. Social sciences teachers at Junior High School Lab UM make their respective efforts to overcome their enthusiasm.

Volume 7, No. 2, September 2020 
One teacher tries to make students enthusiastic by carrying out outdoor learning to get hands-on experience and gain additional knowledge from the real world. One teacher asks students to do the challenging task of making Mind mapping and making cross-puzzle questions (TTS). One teacher, others attempt to make interlude activities for students in Ice breaking during learning. The three strategies carried out by the UM Lab Middle School teachers proved successful in making students interested and enthusiastic in learning.

\section{REFERENCES}

Afdhal, M. (2015, November). Menumbuhkan kemampuan berpikir kritis matematis dan antusiasme belajar melalui pendekatan reciprocal teaching. Paper presented at Seminar Nasional Matematika dan Pendidikan Matematika Universitas Negeri Yogyakarta, Yogyakarta, Indonesia.

Arianti, G. (2017). Kepuasan remaja terhadap penggunaan media sosial instragram dan path. Wacana: Jurnal Ilmiah Ilmu Komunikasi, 16(2), 180-192. doi:https://doi.org/10.32509/wacana.v16i2.21

Beischel, K. P. (2013). Variables affecting learning in a simulation experience: A mixed methods study. Western Journal of Nursing Research, 35(2), 226-247. doi:https://doi.org/10.1177/0193945911408444

Bildhonny, A. F. (2017). Menurunkan kejenuhan belajar siswa dengan teknik relaksasi pada mata pelajaran pendidikan jasmani. Prosiding Seminar Nasional Profesionalisme Tenaga Profesi PJOK, 1(1), 274-280. Retrieved from http://pasca.um.ac.id/conferences/index.php/por/article/viewFile/666/348

Bosah, I., Ejesi, N., \& Doris, A. (2016). Disruptive classroom behaviours among primary school pupils: Intervention imperative. Ideal Journal of Education and Policy Studies, 2, 86-91. Retreived from https://www.researchgate.net/publication/309638244 DISRUPTIVECLASSROOM_BEHAVIOURS_AMONG_PRIMARY_SCHOOL_PUPILS_INTERVE NTION IMPERATIVE

Cresswell, J. (2014). Riset pendidikan: Perencanaan kualitatif dan desain desain riset antara lima pendekatan. (Laznardi, A. L., Trans.). Yogyakarta: Pustaka Belajar

Djamarah, S. B. (2011). Psikologi belajar. Jakarta: Rineka Cipta.

Fitriana, V., \& Triwiyanto, T. (2015). Strategi yayasan untuk menarik minat orang tua dalam menyekolahkan anaknya. Jurnal Manajemen Pendidikan, 25, 224-232.

Gerungan, W. A. (2010). Psikologi sosial. Bandung: Refika Aditama

Gettinger, M., \& Seibert, J. K. (2001). Best practices in increasing academic learning time. Best Practices in School Psychology IV, 1, 773-787. Retrieved from https://www.semanticscholar.org/paper/Best-Practices-in-Increasing-Academic-LearningTime-Gettinger-Seibert/f1542ae1332cdde752d03218a46690ff0ca639b1

Goleman, D. (1998). Working with emotional intelligence. Bantam.

Han, T., Takkaç-Tulgar, A., \& Aybirdi, N. (2019). Factors causing demotivation in EFL learning process and the strategies used by Turkish EFL learners to overcome their demotivation. Advances in Language and Literary Studies, 10(2), 56-65. doi:http://dx.doi.org/10.7575/aiac.alls.v.10n.2p.56

Hapnita, W. (2018). Faktor internal dan eksternal yang dominan mempengaruhi hasil belajar menggambar dengan perangkat lunak siswa kelas XI teknik gambar bangunan SMK N 1 Padang tahun 2016/2017. CIVED (Journal of Civil Engineering and Vocational Education), 5(1), 2175-2182. doi:https://doi.org/10.24036/cived.v5i1.9941 
148 - Harmoni Sosial: Jurnal Pendidikan IPS

Herijanto, B. (2012). Pengembangan cd interaktif pembelajaran ips materi bencana alam. Journal of Educational Social Studies, 1(1), 8-12. Retrieved from https://journal.unnes.ac.id/sju/index.php/jess/article/view/73

Ibrohim, A. (2018). Jejak inovasi pembelajaran IPS: Mengembangkan profesi guru pembelajar. Yogyakarta: LeutikaPrio.

Indianto, A. (2015). Kiat-kiat mempertajam daya ingat hafalan pelajaran. Yogyakarta: DIVA Press

Johan, R., \& Harlan, J. (2014). Education nowadays. International Jounal of Educational Science and Research (IJESR), 4(5), 51-56. Retrieved from http://harlan johan.staff.gunadarma.ac.id/Publications/files/3104/Calculating+Volume+He morrhage+Brain + on + CT-Scan+Image.pdf

Kwan, R., \& Mafe, C. (2016). Rote learning: A necessary evil. Advances in Medical Education and Practice, 7, 429-432. doi:https://doi.org/10.2147/AMEP.S115838

Mahajan, M., \& Singh, M. K. S. (2017). Importance and benefits of learning outcomes. IOSR Journal of Humanities and Social Science, 22(03), 65-67. doi:https://doi.org/10.9790/0837$\underline{2203056567}$

Marini, A. (2016). Enhancement of student learning outcomes through the use of contextual teaching and learning. PONTE International Journal of Sciences and Research, 72(11), 26-43. Retrieved from https://pdfs.semanticscholar.org/956c/9cb9a7b2bd56fd1089d40e2dc559e0509dcb.pdf

Maryani, E., \& Syamsudin, H. (2009). Pengembangan program pembelajaran IPS untuk meningkatkan kompetensi Keterampilan sosial. Jurnal Metodik Didaktik, 9(1), 1-15. Retrieved from http://jurnal.upi.edu/file/Enok_Maryani.pdf

Miles, M. B., \& Huberman, M. Saldana.(2014). Analisis data kualitatif. (Rohidi, T. R., Trans.). Jakarta: UI Press

Moleong, L. J. (2013). Metode penelitian kualitatif. Bandung: Remaja Rosdakarya.

Nawawi, H. (1993). Metode penelitian bidang sosial. Yogyakarta: Gadjah Mada University Press

Truong, T. N., Ngoc, N., Samad, A. A., \& Thompson, J. (2020). A qualitative case study into exploring the learning styles and learning strategies of non English major Vietnamese college students. Universal Journal of Educational Research. 8. 76-86. doi:https://doi.org/10.13189/ujer.2020.081311

Nurfirdaus, N., \& Risnawati, R. (2019). Studi tentang pembentukan kebiasaan dan perilaku sosial siswa (Studi Kasus di SDN 1 Windujanten). Jurnal Lensa Pendas, 4(1), 36-46. doi: https://doi.org/10.33222/jlp.v4i1.486

President of the Republic of Indonesia. (2003). Law of the Republic of Indonesia No. 20 of 2003. Concerning the National Education System.

Qomariyah, L. (2014). Peningkatan motivasi dan hasil belajar IPS melalui model pembelajaran kooperatif dengan teknik Numbered Heads Together (NHT) pada siswa kelas VII B SMP Negeri 2 Tenggarang Bondowoso (Unpublished doctoral dissertation). Universitas Islam Negeri Maulana Malik Ibrahim, Indonesia.

Raja, R., \& Nagasubramani, P. C. (2018). Impact of modern technology in education. Journal of Applied and Advanced Research, 3(1), S33-S35. doi:https://dx.doi.org/10.21839/jaar.2018.v3S1.165

Rosyid, M. Z., Mustajab, M., \& Abdullah, A. R. (2019). Prestasi belajar. Literasi Nusantara.

Rukajat, A. (2018). Pendekatan penelitian kualitatif (Qualitative research approach). Yogyakarta: Deepublish. 
Sardiman, A. M. (2016). Interaksi \& motivasi belajar mengajar. Jakarta: Raja Gravindo Persada

Sari, Y. I., \& Kurniawati, D. (2016). Pengaruh motivasi penilaian K-13 terhadap hasil belajar IPS siswa di SMP Nasional Kota Malang. JPIG (Jurnal Pendidikan dan Ilmu Geografi), 1(1), 1 6. Retrieved from http://ejournal.unikama.ac.id/index.php/JPIG/article/view/1458/1135

Schaufeli, W. B., \& Enzmann, D. (1998). The burnout companion to study and practice: A critical analysis. United Kingdom: CRC Press

Serin, H. (2017). The role of passion in learning and teaching. International Journal of Social Sciences \& Educational Studies, 4(1), 60-64. doi:https://doi.org/10.23918/ijsses.v4i1p60

Setyowati, R., \& Firmansyah, W. (2018). Upaya peningkatan citra pembelajaran IPS bermakna di Indonesia. Jurnal Pendidikan Ilmu Pengetahuan Sosial Indonesia, 3(1), 14-17. doi: http://dx.doi.org/10.26737/jpipsi.v3i1.544

Soenarno, A. (2005). Ice breaker: Permainan atraktif-edukatif untuk pelatihan manajemen. Yogyakarta: Andi.

Suciyanto, A. D. (2013). Upaya meningkatan minat dan hasil belajar IPS menggunakan metode teka-teki silang di Kelas VIII C SMP Negeri 2 Prambanan (Unpublished bachelor's thesis). Universitas Negeri Yogyakarta, Indonesia.

Sukmadinata, N. S. (2005). Metode penelitian pendidikan. Bandung: PT Remaja Rosdakarya.

Suryati, T., \& Suryana, K. (2019). The effect of e-learning based on schoology and student interest to metacognitive thinking skill of vocational high school students in archival subject. International Journal of Research \& Review, 6(12), 397-404. Retrieved from https:/www.academia.edu/download/63652532/IJRR005420200616-53978-zhypel.pdf

Suwarna, A. M. (2001). Epistemologi pendidikan imu pengetahuan sosial. Bandung: Gelar Pustaka Mandiri.

Suyono, H. (2015). Implementasi belajar dan pembelajaran. Bandung: Remaja Rosdakarya.

Tobeli, E. (2010). Upaya peningkatan efektifitas belajar peserta didik SMA dengan pengembangan kecerdasan intra pribadi dan antar pribadi. PANABIBLOS: Jurnal Pendidikan Agama Kristen, Musik Gereja dan Teknologi Konseling Kristen, 1(2). Retrieved from http://www.ejurnal.ukrimuniversity.ac.id/file/p126.pdf

Valverde-Berrocoso, J., Garrido-Arroyo, M. D. C., Burgos-Videla, C., \& Morales-Cevallos, M. B. (2020). Trends in educational research about e-learning: A systematic literature review (2009-2018). Sustainability, 12(12), 5153. doi:https://doi.org/10.3390/su12125153

Wicaksono, R. (2013). Raising students' awareness of the construction of communicative (in) competence in international classrooms. Cross-cultural teaching and learning for home and international students: Internationalisation of pedagogy and curriculum in higher education, 241-250.

Widiansyah, A. (2018). Peranan sumber daya pendidikan sebagai faktor penentu dalam manajemen sistem pendidikan. Cakrawala : Jurnal Humaniora Bina Sarana Informatika, 18(2), 229234. doi: https://doi.org/10.31294/jc.v18i2.4347

Winkel, G., Saegert, S., \& Evans, G. W. (2009). An ecological perspective on theory, methods, and analysis in environmental psychology: Advances and challenges. Journal of Environmental Psychology, 29(3), 318-328. doi:https://doi.org/10.1016/j.jenvp.2009.02.005

Yosodipuro, A. (2013). Peserta didik senang pendidik gemilang: Strategi mengajar yang menyenangkan dan mendidik dengan cerdik. Jakarta: Kompas Gramedia. 